Praxis : Jurnal Sains, Teknologi, Masyarakat dan Jejaring | Vol. 4 | No. 1 | September 2021

\title{
Analisis Pengaruh Kepemilikan Asing Terhadap Volatilitas Return Saham, Volume Perdagangan, Dan Risiko Saham Di Indonesia
}

\author{
Desy Febriana Sari, Hersugondo* \\ Departemen Manajemen Fakultas Ekonomika dan Bisnis Universitas Diponegoro \\ *email korespondensi: hersugondo@lecturer.undip.ac.id
}

\begin{abstract}
Abstrak
Penelitian ini bertujuan untuk mengetahui pengaruh kepemilikan asing terhadap volatilitas, volume perdagangan, dan risiko saham pada perusahaan yang terdaftar dalam indeks LQ45 di Bursa Efek Indonesia pada periode tahun 2018 - 2020. Sampel diambil dengan menggunakan metode purposive dan diperoleh jumlah sampel sebanyak 21 perusahaan. Data yang digunakan adalah data sekunder. Metode analisis data yang digunakan adalah regresi linear berganda dengan level of significant sebesar 0,05. Hasil penelitian ini menunjukkan bahwa : Kepemilikan asing berpengaruh positif dan signifikan terhadap volatilitas return saham, kepemilikan asing tidak berpengaruh signifikan terhadap volume perdagangan, kepemilikan asing berpengaruh positif dan signifikan terhadap risiko saham.
\end{abstract}

Kata Kunci : Kepemilikan Asing, Risiko Saham, Volume Perdagangan, Volatilitas return Saham.

\begin{abstract}
This study aims to determine the effect of foreign ownership on volatility, trading volume, and stock risk in companies listed in the LQ45 index on the Indonesia Stock Exchange. The research period used was 2018-2020. Samples were taken using a purposive method and obtained a total sample of 21 companies. The data used are secondary data. The data analysis method used is multiple linear regression with a level of significance of 0.05 . The results of this study indicate that: Foreign ownership has a positive and significant effect on stock return volatility, foreign ownership has no significant effect on trading volume, foreign ownership has a positive and significant effect on stock risk.
\end{abstract}

Keywords: Foreign Ownership, Stock return Volatility, Stock Risk, Trading Volume.

\section{PENDAHULUAN}

Globalisasi memberikan pengaruh yang besar terhadap kegiatan perekonomian. Globalisasi membuat batas negara seolaholah menjadi tidak ada (Friedman, 2007). Jarak geografis menjadi tidak terlalu signifikan lagi karena semakin besarnya luas jangkauan dan kecepatan informasi yang menjadikan aktivitas keuangan global lebih efisien, termasuk dalam kegiatan pasar modal di Indonesia. Hal itu memudahkan investor asing untuk berinvestasi pada perusahaan domestik.
Pasar modal merupakan sumber keuangan bagi pertumbuhan perusahaan. Pasar modal berfungsi sebagai wahana untuk menyalurkan dana dari pihak yang mempunyai kelebihan dana kepada pihak yang membutuhkan dana. Pasar modal merupakan sumber pembiayaan jangka panjang bagi perusahaan, dan menjadi sarana investasi bagi para investor lokal maupun asing. Sebagai emiten, perusahaan harus mampu menunjukan kepada masyarakat/ investor bahwa efek yang diterbitkannya memang layak untuk diperdagangkan di bursa. 
Praxis : Jurnal Sains, Teknologi, Masyarakat dan Jejaring | Vol. 4 | No. 1 | September 2021

Meningkatnya peran asing dalam pasar modal Indonesia semakin signifikan yang diindikasikan dengan transaksi pemodal yang terbilang cukup aktif di Bursa Efek Indonesia (BEI). Berdasarkan nilai efek yang tersimpan di Kustodian Sentral Efek Indonesia (KSEI), per 9 Agustus 2019, investor asing menggenggam sebesar Rp1.907 triliun setara 51,46 persen dari total ekuitas. Sementara, porsi investor domestik tercatat Rp1.799 triliun atau setara 48,54 persen. Dengan mendominasinya asing dipasar memberikan konsekuensi untung rugi bagi pasar modal, salah satu kerugiannya adalah jika porsi asing terlalu besar, pasar modal akan jatuh ketika memutuskan melarikan dananya ke luar (www.cnnindonesia.com).

Hal itu menjadi perdebatan mengenai manfaat yang didapatkan serta ke khawatiran bagi perusahaan domestic. Pada dasarnya, derasnya aliran modal asing yang masuk ke Indonesia telah menjadi fenomena yang umum sejak krisis Asia pada pertengahan 1998 yang dipicu oleh krisis mata uang dan pasar modal serta krisis global tahun 2008 yang dipicu oleh kejatuhan sub-prime mortgage. Oleh karena itu, derasnya aliran modal asing yang masuk ke negara Indonesia, mengacu pada kebijakan moneter Indonesia, dalam ini suku bunga yang relatif tinggi dianggap menjanjikan imbal hasil ( return) yang lebih bagi investor. Hal ini mengakibatkan Indonesia memiliki ketergantungan pada negara maju sebagai investor utama.

Dalam konteks pasar modal, ketergantungan yang cukup besar pada negara maju dikahwatirkan meningkatkan risiko yang dihadapi atau membuat volatilitas dipasar modal relative tinggi. Volatilitas ini merupakan indicator risiko relative harga saham, dimana semakin besar volatilitas maka semakin besar pula risikonya. Dapat dilihat penanaman modal asing Indonesia dilaporkan sebesar USD 5.1 miliar pada Desember 2020. Rekor ini naik dibanding sebelumnya yaitu USD 4.1 miliar pada September 2019. Data penanaman modal asing Indonesia diperbarui triwulanan, dengan rata-rata USD 523.3 juta bulan Maret tahun 1981 sampai dengan bulan Desember tahun 2020, dengan 160 observasi. Data ini mencapai angka tertinggi sebesar USD 8,8,1 miliar pada September 2017 dan rekor terendah sebesar USD - -9,3 miliar pada Desember 2016.

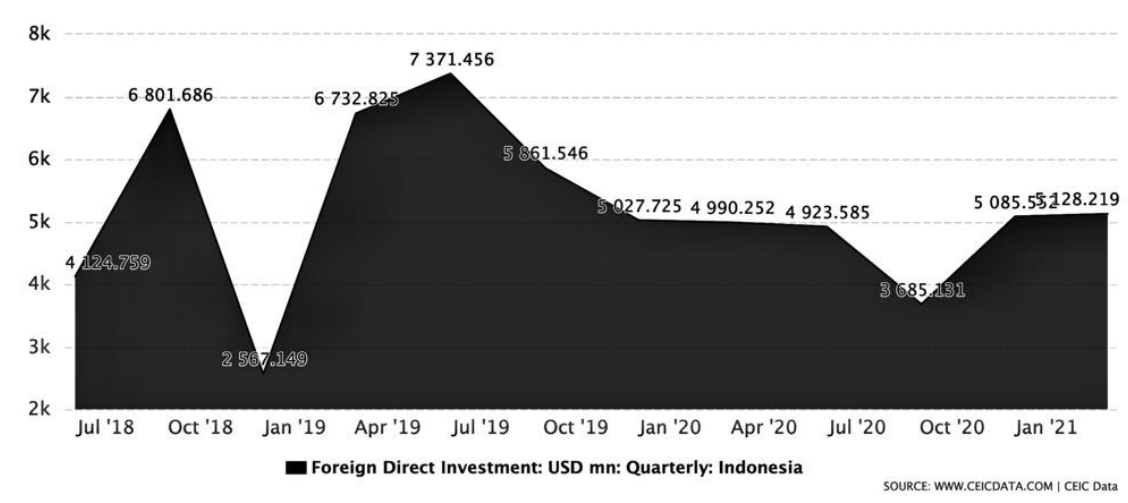

Gambar 1. Indonesia Foreign Direct Invesment (www.ceicdata.com)

Dalam laporan terbaru Indonesia, Transaksi Berjalan mencatat surplus sebesar 795,5 USD mn pada 2020. Investasi Langsung Indonesia di Luar Negeri diperluas sebesar 870,4 USD mn pada 2020. Investasi Portofolio Luar Negeri meningkat sebesar 2,8 USD bn pada 2020. PDB Nominal negara itu dilaporkan sebesar 273,1 USD bn pada 2020. (sumber : CEIC Data)i. Kepemilikan 
Praxis : Jurnal Sains, Teknologi, Masyarakat dan Jejaring | Vol. 4 | No. 1 | September 2021

asing di pasar saham Indonesia memberikan dampak yang cukup signifikan terhadap pergerakan harga saham di Bursa Efek Indonesia. Keberadaan investor asing ini memang memberikan pengaruh positif karena membuat bursa saham lebih likuid. Disisi lain, dominasi kepemilikan saham oleh investor asing membuat kinerja pasar modal bisa sangat fluktuatif karena adanya potensi penarikan dana setiap saat. Selain itu kemudahan keluar masuk pasar saham Indonesia membuat dana investor asing memiliki tingkat likuiditas yang cukup tinggi, sehingga investor asing bisa saja mengucurkan dana segar maupun menarik dananya dari pasar modal Indonesia dalam waktu singkat, hal ini berpengaruh terhadap stabilitas pasar saham Indonesia.

Beberapa penelitian di berbagai negara tersebut telah dilakukan karena masih adanya perdebatan mengenai faktor-faktor apa saja yang berpengaruh terhadap kepemilikan saham. Salah satunya yang dilakukukan Wang (2007) yang menguji bagaimana kepemilikan asing mempengaruhi volalitas saham di Indonesia, Wang menunjukkan bahwa kepemilikan asing mempunyai pengaruh dapat mengurangi volalitas saham. Artinya, kepemilikan asing dipandang positif karena mampu menurunkan risiko. Hal ini bertolak belakang dengan negaranegara maju yang mengindikasikan bahwa terdapat perbedaan mekanisme ekonomi yang membawa pada dampak volalitas yang bertolak belakang.

Berdasarkan fenomena dan teori yang diungkapkan di atas, maka peneliti tertarik untuk melakukan penelitian dengan mangambil perusahaan LQ 45 yang terdaftar di Bursa Efek Indonesia periode tahun 2018-2020. Terdapat tiga rumusan masalah : Kepemilikan asing berpengaruh positif terhadap volatilitas return saham, kepemilikan asing berpengaruh positif terhadap volume perdagangan, kepemilikan asing berpengaruh positif terhadap risiko saham. Hal itu bertujuan untuk menganalisis pengaruh kepemilikan asing terhadap volatilitas return saham, volume perdagangan, dan risiko saham.

\section{TINJAUAN PUSTAKA}

\subsection{Kepemilikan Asing dan Volatilitas return Saham}

Dampak kepemilikan asing masih bisa diperdebatkan. Pertama, kepemilikan asing memiliki korelasi negatif dengan volatilitas pengembalian. Chiang dan Chan (2017) menemukan bahwa kepemilikan asing menyebabkan volatilitas return saham yang lebih rendah di Taiwan karena efek stabilisasi. Mekanisme ekonomi dari efek ini disebabkan oleh peningkatan pengungkapan dan operasi. Pemegang saham asing memperoleh kualitas informasi yang lebih baik, dan dapat mengontrol dan melaporkan biaya transaksi mereka dengan lebih efisien (Vo, 2015); mereka meningkatkan tata kelola perusahaan (Ang et al., 2010; Min dan Bowman, 2015), dan juga pembagian risiko, pemantauan, dan pengambilan keputusan keuangan (Li et al., 2011), sekaligus meningkatkan keakuratan informasi publik dan mengurangi volatilitas (Umutlu et al., 2010). Kedua, kepemilikan asing berdampak positif pada volatilitas pengembalian. Chen dkk. (2013) menemukan bahwa, di Tiongkok, semakin besar kepemilikan asing, semakin tinggi volatilitas return saham, karena dampak penguatan likuiditas dan volatilitas. Umutlu dan Shackleton (2015) menyatakan bahwa perdagangan luar negeri neto memiliki pengaruh yang meningkat terhadap volatilitas, meskipun tidak selalu signifikan. Che (2018) menunjukkan bahwa investor asing meningkatkan volatilitas return saham sejak saat itu pedagang momentum dengan cakrawala investasi pendek. Berdasarkan 
Praxis : Jurnal Sains, Teknologi, Masyarakat dan Jejaring | Vol. 4 | No. 1 | September 2021

penalaran di atas, maka hipotesis pertama diajukan adalah:

\section{$\mathrm{H}_{1}$ : Kepemilikan asing memiliki pengaruh positif dengan volatilitas return saham.}

\subsection{Kepemilikan Asing dan Volumen Perdagangan}

Uraian kedua adalah apakah kepemilikan asing memiliki pengaruh dengan volume perdagangan saham perusahaan. Menurut Rhee dan Wang (2009), kepemilikan asing menurunkan likuiditas masa depan, karena kepemilikan asing yang lebih besar berpengaruhdengan likuiditas yang lebih rendah. Lee dan Chung (2017) menemukan bahwa koefisien korelasi antara kepemilikan asing dan volume perdagangan harian secara signifikan negatif karena meningkatnya persaingan dalam proses penemuan harga. Ngo dkk. (2019) menyatakan terdapat pengaruh kepemilikan asing karena peningkatan rasio kepemilikan asing mengakibatkan peningkatan likuiditas saham. Sebaliknya, kepemilikan asing memiliki pengaruh positif dengan volume perdagangan. Ghadhab (2016) menemukan bahwa kepemilikan asing yang lebih tinggi menghasilkan lebih banyak saham yang diperdagangkan. Vo (2017) juga menemukan bahwa peningkatan kepemilikan asing pada perusahaan lokal memiliki pengaruh positif dengan saham yang diperdagangkan oleh investor asing. Saham yang informasinya diperoleh investor asing, dengan biaya lebih rendah, mengalami volume penjualan yang lebih tinggi (Dodd et al., 2015). Berdasarkan penalaran di atas, maka hipotesis kedua diajukan adalah:

\section{H2$_{2}$ Kepemilikan asing memiliki pengaruh positif dengan volume perdagangan.}

\subsection{Kerangka Pemikiran}

\subsection{Kepemilikan Asing dan Risiko Saham}

Uraian ketiga adalah apakah kepemilikan asing memiliki pengaruh dengan risiko yang terlibat dalam perdagangan saham; karena kepemilikan asing dikaitkan dengan risiko yang lebih tinggi. Jika pemiliknya, yaitu investor asing, adalah risk taker, maka risiko sahamnya meningkat. Investor internasional meningkatkan risiko karena risiko tersebut tidak hanya dihadapi oleh investor domestik tetapi juga oleh investor asing karena mereka memiliki andil dalam perekonomian negara. Fiala dan Havranek (2017) menemukan bahwa kepemilikan asing dapat menjadi sumber risiko, terutama pada saat krisis keuangan. Ngo dkk. (2019) mengungkapkan bahwa peningkatan rasio kepemilikan asing membawa risiko yang lebih tinggi pada saham perusahaan. Di sisi lain, kepemilikan asing memiliki pengaruh negatif dengan risiko. Beberapa studi berpendapat bahwa membuka pasar bagi investor internasional, karena liberalisasi, mendorong pertumbuhan ekonomi dan pembagian risiko (Li et al., 2011). Investor asing membantu mengurangi risiko yang dihadapi oleh perusahaan tempat mereka berinvestasi (Umutlu et al., 2010). Pemilik dapat menghilangkan risiko karena berkontribusi pada preferensi yang sesuai, pengambilan keputusan, dan struktur modal (Ang et al., 2010). Lassoued dkk. (2016) menemukan bahwa kepemilikan asing mengurangi pengambilan risiko karena merupakan pendorong penting dari stabilitas ekonomi suatu negara. Berdasarkan penalaran di atas, maka hipotesis ketiga diajukan adalah:

\section{H3: Kepemilikan asing memiliki pengaruh positif dengan risiko.}


Praxis : Jurnal Sains, Teknologi, Masyarakat dan Jejaring | Vol. 4 | No. 1 | September 2021

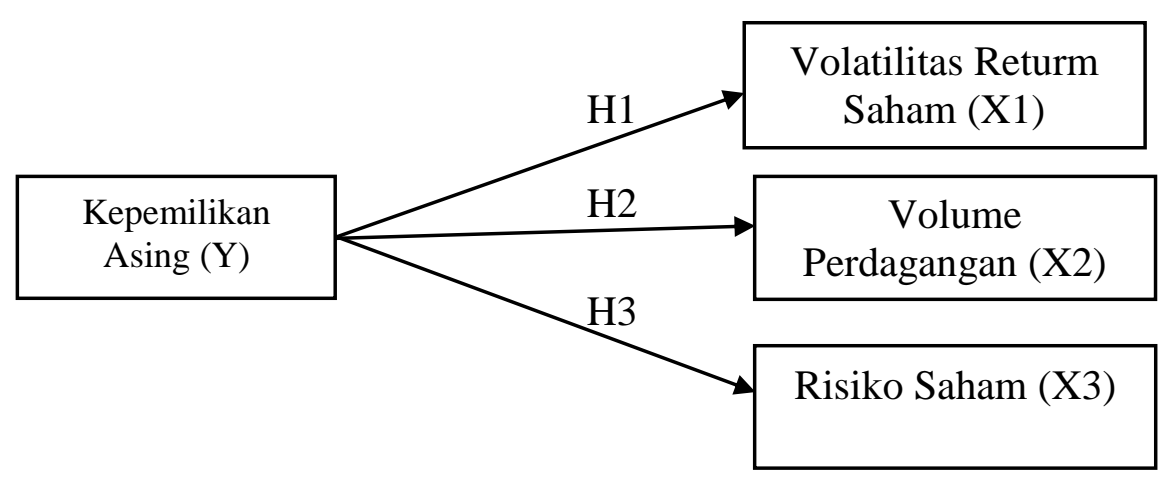

Gambar 2. Kerangka Pemikiran

\section{METODE PENELITIAN}

\subsection{Data dan Metode}

Sampel penelitian terdiri dari perusahaan yang masuk dalam indeks LQ45 yang sudah dan masih terdaftar di Bursa Efek
Indonesia periode 2018-2020. Data yang digunakan dalam penelitian ini diakses dari www.idx.co.id. Sampel dipilih menggunakan purposive sampling, dimana perusahaan harus memenuhi kriteria sebagai berikut:

Tabel 1. Kriteria Purposive Sampling

\begin{tabular}{|c|l|}
\hline $\mathbf{1 .}$ & $\begin{array}{l}\text { Perusahaan yang dijadikan sampel adalah perusahaan yang secara konsisten } \\
\text { masuk sebagai anggota indeks LQ45 periode 2018-2020. }\end{array}$ \\
\hline $\mathbf{2 .}$ & $\begin{array}{l}\text { Perusahaan yang konsisten terdaftar dalam periode penelitian sebanyak } 21 \\
\text { perusahaan }\end{array}$ \\
\hline $\mathbf{3 .}$ & $\begin{array}{l}\text { Data yang digunakan dasar perhitungan adalah data bulanan, baik untuk } \\
\text { harga saham, return saham, maupun indeks harga saham selama periode } \\
\text { yang diteliti. }\end{array}$ \\
\hline $\mathbf{4 .}$ & $\begin{array}{l}\text { Data harga saham bulanan yang digunakan adalah harga saham penutupan } \\
\text { (closing price) }\end{array}$ \\
\hline
\end{tabular}

Data yang dibutuhkan adalah data sekunder. Data sekunder adalah data yang diperoleh dari pihak lain dalam bentuk yang sudah jadi dan dipublikasikan untuk umum. Teknik pengumpulan data dalam penelitian ini dilakukan dengan metode dokumentasi, yaitu metode pengumpulan data yang berasal dari catatan atau data tertulis yang berpengaruhdengan objek yang diteliti. Metode dokumentasi yang digunakan dalam penelitian ini dilakukan dengan mengumpulkan data yang diperoleh dari www.idx.co.id dan www.ksei.co.id.
Teknik analisis regresi yang digunakan dalam penelitian ini adalah R-Square (Adjusted R-Square dan uji signifikansi simultan (Uji statistic F) untuk menguji hipotesis yang kami usulkan dalam penelitian ini. Kami memilih analisis uji parsial (Uji statistic T) ini karena dapat menguji pengaruh dan signifikansi dari masing-masing variabel independen dan variabel dependen; Meskipun bukan merupakan metode regresi terbaik, namun harus memenuhi asumsi Gauss - Markov seperti normalitas, multikolinearitas, autokorelasi, dan heteroskedastisitas untuk mendapatkan Best Linear Un bias 
Praxis : Jurnal Sains, Teknologi, Masyarakat dan Jejaring | Vol. 4 | No. 1 | September 2021

Estimator (BLUE) dari hasil estimasi (Wooldridge, 2012).

\subsection{Definisi Operasional variable}

Variabel dependen merupakan variabel yang dipengaruhi oleh variabel-variabel independen. Variabel dependen yang digunakan dalam penelitian ini adalah kepemilikan asing. Kepemilikan asing adalah proporsi kepemilikan saham pada perusahaan yang dimiliki oleh pihak asing baik secara individu maupun kelompok. Menurut Farooque et al., (2007) dalam Wiranata dan Nugrahanti (2013) memberikan definisi bahwa kepemilikan asing merupakan proporsi outstandingshare yang dimiliki oleh investor atau pemodal asing (foreign investors) yakni perusahaan yang dimiliki oleh 38 perorangan, badan hukum, pemerintah serta bagian-bagiannya yang berstatus luar negeri terhadap jumlah seluruh modal saham yang beredar.

Variabel independen merupakan variabel yang memengaruhi atau yang menjadi sebab perubahan atau timbulnya variabel dependen. Variabel independen yang digunakan dalam penelitian ini adalah return volatilitas volume perdagangan, dan risiko saham akan dijelaskan dibawah ini:

\section{a. Volatilitas return Saham}

Volatilitas adalah ukuran statistik untuk fluktuasi harga selama periode tertentu (Firmansyah, 2006). Volatilitas yang tinggi menunjukan harga saham bergerak naik dan turun secara cepat. Semakin tinggi volatilitas, maka potensi return akan semakin tinggi. Volatilitas yang rendah menunjukkan 31 kestabilan nilai return, akan tetapi umumnya returnnya tidak terlalu tinggi. Secara matematis, volatilitas harga untuk setiap saham ditunjukkan dengan rumus berikut (Parkinson, 1980):

b. Volume perdagangan

Volume perdagangan saham merupakan jumlah lembaran saham suatu emiten yang diperjualbelikan di pasar modal setiap hari dengan tingkat harga yang disepakati oleh pihak penjual dan pembeli saham. Volume perdagangan seringkali dijadikan tolok ukur (benchmark) untuk mempelajari informasi dan dampak dari berbagai kejadian.

c. Risiko saham

Peneliti menggunakan dua proxy untuk mengukur yaitu return on Assets (ROA) triwulanan, sebagai proksi dari risiko aset, dan return on Equity (ROE) triwulanan sebagai proxy dari risiko ekuitas.

\section{HASIL DAN PEMBAHASAN}

\subsection{Statistik Deskriptif}

Hasil statistik data variabel-variabel yang digunakan dalam penelitian ini dan telah dilakukan pegelolaan data adalah sebagai berikut : 
Praxis : Jurnal Sains, Teknologi, Masyarakat dan Jejaring | Vol. 4 | No. 1 | September 2021

Tabel. 2 Statistik Deskriptif

\begin{tabular}{lr|r|r|r|r} 
& & \multicolumn{5}{|c}{ Statistik Deskriptif } & \\
& $\mathrm{N}$ & Minimum & \multicolumn{1}{c}{ Maximum } & \multicolumn{1}{c}{ Mean } & Std. Deviation \\
\hline $\begin{array}{l}\text { Kepemilikan } \\
\text { Asing }\end{array}$ & 61 & 0.06 & 0.59 & 0.2594 & 0.10389 \\
\hline Volatilitas & 61 & 0.00 & 0.20 & 0.0200 & 0.03486 \\
\hline $\begin{array}{l}\text { Volume } \\
\text { ROA }\end{array}$ & 61 & 1373600.00 & 300114300.00 & 50065308.1967 & 65888008.39107 \\
\hline ROE & 61 & -0.60 & 0.46 & 0.0991 & 0.16791 \\
\hline $\begin{array}{l}\text { Valid N } \\
\text { (listwise) }\end{array}$ & 61 & -0.15 & 1.40 & 0.0834 & 0.23487 \\
\hline & 61 & & & & \\
\hline
\end{tabular}

Sumber : Data sekunder yang diolah, 2021

Berdasarkan tabel di atas statistik deskriptif dapat diketahui bahwa nilai minimum kepemilikan asing sebesar 0.06 dan nilai maksimum sebesar 0.59. hasil tersebut menunjukkan bahwa besar kepemilikan asing perusahaan LQ45 yang menjadi sampel penelitian ini berkisar antara 0.06 sampai 0.59 dengan rata-rata 0.2594 pada standar deviasi 0.10389 . nilai rata-rata lebih besar dari standar deviasi yaitu 0,2594>0.10389, bearti bahwa sebaran nilai kepemilikan asing baik.

Berdasarkan tabel di atas statistik deskriptif dapat diketahui bahwa nilai minimum volatilitas sebesar 0.00 dan nilai maksimum sebesar 0.20. hasil tersebut menunjukkan bahwa besar volatilitas perusahaan LQ45 yang menjadi sampel penelitian ini berkisar antara 0.00 sampai 0.20 dengan rata-rata 0.0200 pada standar deviasi 0.03486 . nilai rata-rata lebih kecil dari standar deviasi yaitu $0,0200<0.03486$, bearti bahwa sebaran nilai volatilitas tidak baik. Volatilitas tertinggi terjadi pada perusahaan SMRA yaitu sebesar 0,009939962, sedangkan volatilitas terendah terjadi pada perusahaan BBCA sebesar 0,00011591.

Berdasarkan tabel di atas statistik deskriptif dapat diketahui bahwa nilai minimum volume sebesar 1373600.00 dan nilai maksimum sebesar 300114300.00. hasil tersebut menunjukkan bahwa besar volume perusahaan LQ45 yang menjadi sampel penelitian ini berkisar antara 1373600 sampai 300114300 dengan ratarata 50065308.1967 pada standar deviasi 65888008.39107. nilai rata-rata lebih kecil dari standar deviasi yaitu 50065308.1967<65888008.39107, bearti bahwa sebaran nilai volume tidak baik.

Berdasarkan tabel di atas statistic deskriptif dapat diketahui bahwa nilai minimum ROA sebesar -0,60 dan nilai maksimum sebesar 0.46 dan ROE sebesar $-0,15$ dan nilai maksimum sebesar 1,40. hasil tersebut menunjukkan bahwa besar ROA dan ROE perusahaan LQ45 yang menjadi sampel penelitian ini berkisar ROA antara -0.60 sampai 0.46 dan ROE antara $-0,15$ sampai 1,40. dengan rata-rata ROA 0,991 pada standar deviasi 0.16791 dan ROE 0,0834 pada standar deviasi 0,23487 . nilai rata-rata lebih kecil dari standar deviasi ROA yaitu $-0,60<0,46$ dan ROE yaitu $0,15<1,40$, bearti bahwa sebaran nilai ROA dan ROE tidak baik.

\subsection{Uji Asumsi Klasik}

\subsubsection{Uji Normalitas}

Uji normalitas data dilakukan dengan maksud untuk menguji apakah dalam 
Praxis : Jurnal Sains, Teknologi, Masyarakat dan Jejaring | Vol. 4 | No. 1 | September 2021

model regresi, variabel dependen dan variabel independen mempunyai distribusi normal atau tidak (Ghozali, 2011). Uji normalitas data yang digunakan dalam penelitian ini adalah dengan kolmogorovsmirnov test. Melalui uji kolmogorovsmirnov dapat diketahui data yang digunakan berdistribusi normal atau tidak. Hipotesis yang digunakan adalah:

H0 : Data residual berdistribusi normal
Ha : Data residual tidak berdistribusi normal

Data penelitian dikatakan menyebar normal atau memenuhi uji normalitas apabila nilai Sig variabel residual berada di atas 0,05 atau 5\%, sebaliknya jika nilai Sig variabel residual berada di bawah 0,05 atau $5 \%$, maka data tersebut tidak berdistribusi normal atau data tidak memenuhi uji normalitas. Hasil pengujian yang diperoleh adalah sebagai berikut:

Tabel. 3 Uji Normalitas

\begin{tabular}{|c|c|c|c|c|c|c|}
\hline & \multicolumn{3}{|c|}{ Kolmogorov-Smirnov ${ }^{a}$} & \multicolumn{3}{|c|}{ Shapiro-Wilk } \\
\hline & Statistic & $d f$ & Sig. & Statistic & $d f$ & Sig. \\
\hline Unstandardized Residual & 0,060 & 61 & $0,200^{*}$ & 0,979 & 61 & 0,379 \\
\hline \multicolumn{7}{|c|}{ *. This is a lower bound of the true significance. } \\
\hline \multicolumn{7}{|c|}{ a. Lilliefors Significance Correction } \\
\hline
\end{tabular}

Sumber : Data sekunder yang diolah, 2021

Berdasarkan hasil uji normalitas menggunakan uji Kolmogorov Smirnov, didapatkan nilai Sig sebesar 0,200 jauh diatas $\alpha=0,05$. Hal ini berarti hipotesis nol (H0) diterima atau data berdistribusi secara normal.

\subsubsection{Uji Multikolinearitas}

Uji multikolonieritas digunakan untuk menguji adanya pengaruh yang sempurna atau pengaruh yang hampir sempurna di antara variabel bebas pada model regresi. Model regresi yang baik seharusnya tidak terjadi multikolinieritas. Uji ini dilakukan dengan melihat nilai Variance Inflation Factor (VIF) dan nilai tolerance value. Jika nilai VIF tidak lebih dari 10 dan nilai Tolerance tidak kurang dari 0,1, maka model dapat dikatakan terbebas dari multikolonieritas. Hasil uji multikolinieritas:

Tabel 4. Uji Multikolinearitas

\begin{tabular}{llll}
\hline \multirow{2}{*}{ Model } & & \multicolumn{2}{l}{$\begin{array}{l}\text { Collinearity } \\
\text { Statistics }\end{array}$} \\
\cline { 2 - 4 } & & Tolerance & VIF \\
\hline 1 & Volatilitas & 0,883 & 1,132 \\
\cline { 2 - 4 } & LN_volum & 0,851 & 1,175 \\
& e & & \\
\cline { 2 - 4 } & ROA & 0,830 & 1,205 \\
\cline { 2 - 4 } & ROE & 0,815 & 1,227 \\
\hline
\end{tabular}

a. Dependent Variable: Kepemilikan Asing

Sumber : Data sekunder yang diolah, 2021

Berdasarkan uji multikolinieritas diatas, hasil perhitungan menunjukkan bahwa tidak ada variabel bebas yang mempunyai nilai tolerance $\leq 0,1$. Hal yang sama ditujukkan oleh nilai VIF, dimana tidak ada variabel bebas yang mempunyai nilai VIF $\geq 10$, sehingga dapat disimpulkan bahwa model regresi pada penelitian ini 
Praxis : Jurnal Sains, Teknologi, Masyarakat dan Jejaring | Vol. 4 | No. 1 | September 2021

tidak terjadi multikolinieritas dan model regresi layak digunakan.

\subsubsection{Uji Autokorelasi}

Uji Autokorelasi dimaksudkan untuk mengetahui apakah dalam model regresi linier ada pengaruh antara kesalahan pengganggu pada periode $t$ dengan kesalahan pada periode t-1 (sebelumnya). Masalah ini sering muncul pada data yang didasarkan waktu berkala seperti bulanan atau tahunan. Dalam model analisis regresi linier berganda juga harus bebas dari autokorelasi. Terdapat berbagai metode yang digunkan untuk menguji ada tidaknya gejala autokorelasi, salah satunya adalah menggunakan teknik regresi dengan melihat nilai Durbin-Watson (DW). Hipotesis yang akan diuji dalam penelitian ini adalah:

H0 : Tidak ada autokorelasi

Ha : Ada autokorelasi

Tabel 5. Uji Autokorelasi

\begin{tabular}{lccccr}
\hline Model & $\mathrm{R}$ & $\mathrm{R}$ Square & $\begin{array}{c}\text { Adjusted R } \\
\text { Square }\end{array}$ & $\begin{array}{c}\text { Std. Error of } \\
\text { the Estimate }\end{array}$ & $\begin{array}{c}\text { Durbin- } \\
\text { Watson }\end{array}$ \\
\hline 1 & $0.792^{\mathrm{a}}$ & 0.627 & 0.600 & 0.06569 & 2.099 \\
\hline a. Predictors: (Constant), ROE , Volatilitas, LN_volume, ROA \\
b. Dependent Variable: Kepemilikan Asing \\
Sumber: Data sekunder yang diolah, 2021
\end{tabular}

Berdasarkan hasil di atas, hasil pengujian diperoleh nilai durbin-watson sebesar 2,099. Nilai Durbin-Watson tersebut kemudian dibandingkan dengan nilai du dan 4-du. Nilai du diambil dari tabel Durbin-Watson dengan $\mathrm{n}=63$ dan $\mathrm{k}=3$, sehingga diperoleh du sebesar 1,693, kemudian dilakukan pengambilan keputusan dengan ketentuan du $<\mathrm{d}<4$-du $(1,693<2,099<4-1,693=2,307)$. Hal ini berarti H0 diterima atau tidak terjadi autokorelasi antara variabel independen, sehingga model regresi layak untuk digunakan.

\subsubsection{Uji Heteroskedasititas}

Heteroskedastisitas merupakan ketidaksamaan variasi variabel pada semua pengamatan dan kesalahan yang terjadi yang memperlihatkan pengaruh sistematis sesuai dengan besarnya satu atau lebih variabel bebas sehingga kesalahan tersebut tidak random. Untuk menguji ada atau tidaknya heteroskedastisitas dapat dilakukan dengan uji glejser. Hipotesis yang digunakan dalam pengujian heteroskedastisitas adalah sebagai berikut:

H0 : Tidak ada heteroskedastisitas

Ha : Ada heteroskedastisitas.

Dasar pengambilan keputusannya adalah, jika signifikansi $(\alpha)<0,05$, maka $\mathrm{H} 0$ ditolak (ada heteroskedastisitas). Jika signifikansi $(\alpha)>0,05$, maka H0 diterima (tidak ada heteroskedastisitas). Apabila koefisiensi signifikansi (nilai probabilitas) lebih besar dari signifikansi yang ditetapkan, maka dapat disimpulkan tidak terjadi heteroskedastisitas. 
Praxis : Jurnal Sains, Teknologi, Masyarakat dan Jejaring | Vol. 4 | No. 1 | September 2021

Tabel 6. Uji Heteroskedastisitas

\begin{tabular}{|c|c|c|c|c|c|c|}
\hline \multirow{2}{*}{\multicolumn{2}{|c|}{ Model }} & \multicolumn{2}{|c|}{$\begin{array}{c}\text { Unstandardized } \\
\text { Coefficients }\end{array}$} & \multirow{2}{*}{$\begin{array}{c}\text { Standardized } \\
\text { Coefficients } \\
\text { Beta }\end{array}$} & \multirow[b]{2}{*}{$\mathrm{t}$} & \multirow[b]{2}{*}{ Sig. } \\
\hline & & B & Std. Error & & & \\
\hline \multirow[t]{5}{*}{1} & (Constant) & 0.127 & 0.041 & & 3.091 & 0.003 \\
\hline & Volatilitas & 0.008 & 0.082 & 0.014 & 0.101 & 0.920 \\
\hline & $\begin{array}{l}\text { LN_volum } \\
\text { e }\end{array}$ & -0.005 & 0.020 & -0.320 & -1.021 & 0.240 \\
\hline & ROA & -0.012 & 0.017 & -0.097 & -0.694 & 0.490 \\
\hline & ROE & -0.014 & 0.013 & -0.161 & -1.142 & 0.258 \\
\hline
\end{tabular}

a. Dependent Variable: AbsRes

Sumber : Data sekunder yang diolah, 2021

Berdasarkan pengujian yang telah dilakukan, pada hasil diatas menunjukkan tidak ada satu pun variabel independen yang signifikan secara statistik. Hal ini terlihat dari probabilitas signifikansinya di atas tingkat kepercayaan 5\%. Jadi dapat disimpulkan model regresi tidak mengandung adanya heteroskedastisitas, maka HO diterima (tidak ada heteroskedastisitas).

\subsection{Hasil Pengujian Ketetapan Model}

\subsubsection{Uji Koefisien Determinasi (Uji R2)}

Koefisien determinasi (Adjusted R2) digunakan untuk mengukur kebaikkan dari persamaan regresi berganda, yaitu memberikan persentase variasi total dalam variabel dependen yang dijelaskan oleh seluruh variabel independen. Dengan kata lain, nilai Adjusted R2 menunjukkan seberapa besar model regresi mampu menjelaskan variabel dependen. Besarnya koefisien determinasi anatar 0 (nol) sampai 1 (satu). Nilai Adjusted R2 yang kecil berarti kemampuan variabel-variabel independen dalam menjelaskan variabel dependen sangat terbatas (Ghozali, 2011). Sebaliknya, jika koefisien determinasi mendekati 1 maka dapat dikatakan semakin kuat model tersebut dalam menerangkan variasi variabel dependen.

\section{Tabel 7. Uji Koefisien Determinasi (Uji R2)}

\begin{tabular}{|c|c|c|c|c|}
\hline \multicolumn{5}{|c|}{ Model Summary ${ }^{b}$} \\
\hline Model & $\mathrm{R}$ & R Square & $\begin{array}{l}\text { Adjusted R } \\
\text { Square }\end{array}$ & $\begin{array}{l}\text { Std. Error of } \\
\text { the Estimate }\end{array}$ \\
\hline 1 & $0.674^{\mathrm{a}}$ & 0.455 & 0.417 & 0.11810 \\
\hline \multicolumn{5}{|c|}{$\begin{array}{l}\text { a. Predictors: (Constant), ROE , Volatilitas, LN_volume, } \\
\text { ROA }\end{array}$} \\
\hline
\end{tabular}

Dari hasil uji adjusted R2, diperoleh sebesar 0,417 atau 41,7\%. Hal ini menunjukkan bahwa kepemilkan asing dipengaruhi oleh volatilitas,volume, ROA dan ROE sebesar 41,7\%. Sedangkan sisanya sebesar $58,3 \%$ dipengaruhi oleh faktor lain yang tidak diteliti dalam penelitian ini.

\subsubsection{Uji Signifikansi Simultan (Uji F)}

Uji $F$ digunakan untuk menguji signifikansi model regresi. Tujuan dari uji 
Praxis : Jurnal Sains, Teknologi, Masyarakat dan Jejaring | Vol. 4 | No. 1 | September 2021

F ini adalah untuk membuktikan secara statistik bahwa keseluruhan koefisien regresi yang digunakan dalam analisis ini signifikan. Apabila nilai signifikansi $F$ lebih kecil dari 0,05 maka model regresi signifikan secara statistik. Untuk menguji hipotesis ini digunakan statistik $\mathrm{F}$ dengan kriteria pengambilan keputusan sebagai berikut:
- Jika tingkat signifikansi lebih besar dari 5\%, maka dapat disimpulkan bahwa $\mathrm{H} 0$ diterima, sebaliknya $\mathrm{Ha}$ ditolak.

- Jika tingkat signifikansi lebih kecil dari 5\%, maka dapat disimpulkan bahwa H0 ditolak, sebaliknya $\mathrm{Ha}$ diterima.

Tabel 8. Uji F

\begin{tabular}{|c|c|c|c|c|c|c|}
\hline \multicolumn{2}{|c|}{ Model } & $\begin{array}{l}\text { Sum of } \\
\text { Squares }\end{array}$ & df & Mean Square & $\mathrm{F}$ & Sig. \\
\hline \multirow[t]{3}{*}{1} & Regression & 0.674 & 4 & 0.169 & 12.088 & $0.000^{\mathrm{b}}$ \\
\hline & Residual & 0.809 & 58 & 0.014 & & \\
\hline & Total & 1.483 & 62 & & & \\
\hline
\end{tabular}

a. Dependent Variable: Kepemilikan Asing

b. Predictors: (Constant), ROE, Volatilitas, LN_volume, ROA

Sumber : Data sekunder yang diolah, 2021

Berdasarkan hasil di atas, dapat dilihat adanya pengaruh volatilitas,volume,ROA dan ROE terhadap kepemilikan asing dari tabel tersebut, diperoleh nilai $\mathrm{F}$ hitung sebesar 12,088 dan signifikansi sebesar 0,000 , sehingga terlihat bahwa nilai signifikansi tersebut lebih kecil dari 0,05. Hal ini menunjukkan bahwa kepemilikan asing berpengaruh terhadap volatilitas, volume, ROA dan ROE pada perusahaan yang terdaftar dalam indeks LQ45 di Bursa Efek Indonesia periode 2018-2020.

\subsection{Uji Hipotesis dan Analisis}

\subsubsection{Uji Regresi Berganda}

Regresi linier berganda ingin menguji pengaruh dua atau lebih variabel independen terhadap satu variabel dependen (Ghozali, 2011) yang dinyatakan sebagai berikut:

$$
\mathrm{Y}=\alpha+(\beta 1 . \mathrm{X} 1)+(\beta 2 \cdot \mathrm{X} 2)+(\beta 3 \cdot \mathrm{X} 3)+\mathrm{e}
$$

Tabel 9. Uji T

\begin{tabular}{|c|c|c|c|c|c|c|}
\hline \multicolumn{7}{|c|}{ Coefficients $^{\mathbf{a}}$} \\
\hline & & $\begin{array}{r}\text { Unstand } \\
\text { Coeffi }\end{array}$ & $\begin{array}{l}\text { rdized } \\
\text { ients }\end{array}$ & $\begin{array}{l}\text { Standardized } \\
\text { Coefficients }\end{array}$ & & \\
\hline \multicolumn{2}{|c|}{ Model } & $\mathrm{B}$ & Std. Error & Beta & $\mathrm{t}$ & Sig. \\
\hline \multirow[t]{5}{*}{1} & (Constant) & 0.370 & 0.224 & & 1.654 & $0.104 *$ \\
\hline & Volatilitas & 1.102 & 0.458 & 0.255 & 2.405 & $0.019 *$ \\
\hline & $\begin{array}{l}\text { LN_volum } \\
\text { e }\end{array}$ & -0.008 & 0.013 & -0.069 & -0.654 & 0.516 \\
\hline & $\mathrm{ROA}$ & 0.437 & 0.096 & 0.496 & 4.571 & $0.000 * *$ \\
\hline & $\mathrm{ROE}$ & -0.206 & 0.071 & -0.309 & -2.906 & $0.005 * *$ \\
\hline
\end{tabular}

a. Dependent Variable: Kepemilikan Asing

Sumber : Data sekunder yang diolah, 2021

Keterangan: *sig 10\%; **sig 5\% 
Praxis : Jurnal Sains, Teknologi, Masyarakat dan Jejaring | Vol. 4 | No. 1 | September 2021

Hasil Pengujian persamaan regresi tersebut dapat dijelaskan sebagai berikut: Kepemilikan saham $=0,370+1,102$ Volatilitas $-0,008$ LN Volume $+0,437$ ROA $0,206 \mathrm{ROE}+\mathrm{e}$

\subsubsection{Uji Parsial (Uji T)}

Uji $\mathrm{T}$ pada dasarnya menunjukkan seberapa jauh pengaruh satu variabel penjelas/independen secara individual dalam menerangkan variasi variabel dependen (Ghozali, 2011). Koefisien regresi digunakan untuk mengetahui pengaruh variabel volatilitas, volume, ROA dan ROE secara parsial terhadap kepemilikan asing. Kriteria pengujian adalah jika tingkat signifikansi lebih besar dari 5\%, maka dapat disimpulkan bahwa H0 diterima, sebaliknya Ha ditolak. Dan jikaa tingkat signifikansi lebih kecil dari 5\%, maka dapat disimpulkan bahwa $\mathrm{H} 0$ ditolak, sebaliknya Ha diterima. Hasil pengujian pengaruh variabel independen terhadap variabel dependennya sebagai berikut:

Berdasarkan pada tabel hasil uji regresi linier berganda diperoleh nilai koefisien regresi sebesar 1,102. Hal ini menunjukkan bahwa pengaruh volatilitas return saham terhadap kepemilikan asing adalah searah. Variabel volatilitas mempunyai $\mathrm{t}$ hitung sebesar 2,405 dengan probabilitas sebesar 0,019. Nilai signifikansi lebih kecil dari tingkat sigifikansi yang diharapkan $(0,019$ $<0,05)$ menunjukkan bahwa variabel kepemilikan asing berpengaruh positif terhada volatilitas return saham pada perusahaan yang terdaftar dalam indeks LQ45 di Bursa Efek Indonesia periode 2018-2020, sehingga hipotesis pertama diterima. Kepemilikan asing memiliki pengaruh positif pada volatilitas return saham. semakin besar kepemilikan asing, semakin tinggi volatilitas return saham, karena dampak penguatan likuiditas dan volatilitas (chen dkk(2013). Che (2018) menunjukkan bahwa investor asing meningkatkan volatilitas return. Jadi, keberadaan pemegang saham asing sangat penting untuk membantu mengurangi volatilitas pengembalian.

Berdasarkan pada tabel hasil uji regresi linier berganda diperoleh nilai koefisien regresi sebesar $-0,008$. Hal ini menunjukkan bahwa pengaruh volume perdagangan terhadap kepemilikan asing adalah berlawan arah. Variabel volume perdagangan mempunyai t hitung sebesar 0,654 dengan probabilitas sebesar 0,516. Nilai signifikansi lebih besar dari tingkat sigifikansi yang diharapkan $(0,516>0,05)$ menunjukkan bahwa variabel kepemilikan asing berpengaruh negatif dan tidak signifikan terhadap volume perdagangan pada perusahaan yang terdaftar dalam indeks LQ45 di Bursa Efek Indonesia periode 2018-2020, sehingga hipotesis kedua ditolak. Kepemilikan asing memiliki pengaruh negatif dengan volume perdagangan. Menurut Rhee dan Wang (2009), kepemilikan asing menurunkan likuiditas masa depan, karena kepemilikan asing yang lebih besar berpengaruhdengan likuiditas yang lebih rendah. Lee dan Chung (2017) menemukan bahwa koefisien korelasi antara kepemilikan asing dan volume perdagangan harian secara signifikan negatif karena meningkatnya persaingan dalam proses penemuan harga. Ngo dkk. (2019) menyatakan terdapat pengaruh kepemilikan asing karena peningkatan rasio kepemilikan asing mengakibatkan peningkatan likuiditas saham.

Berdasarkan pada tabel hasil uji regresi linier berganda diperoleh nilai koefisien regresi ROA sebesar 0,437 dan ROE sebesar -0,206. Hal ini menunjukkan bahwa pengaruh ROA terhadap kepemilikan asing adalah searah tetapi ROE terhadap kepemilikan asing berlawan arah. Variabel ROA mempunyai t hitung sebesar 4,571 dan ROE mempunyai $t$ 
Praxis : Jurnal Sains, Teknologi, Masyarakat dan Jejaring | Vol. 4 | No. 1 | September 2021

hitung -2,906 dengan probabilitas ROA sebesar 0,000 dan ROE sebesar 0,005. Nilai signifikansi lebih kecil dari tingkat sigifikansi yang diharapkan (ROA 0,000 < $0,05$ dan ROE $0,005<0,05)$ menunjukkan bahwa variabel kepemilikan asing berpengaruh positif dan signifikan terhadap risiko saham pada perusahaan yang terdaftar dalam indeks LQ45 di Bursa Efek Indonesia periode 2018-2020, sehingga hipotesis ketiga diterima. Kepemilikan asing memiliki pengaruh positif dengan risiko saham. Jadi, ini mendukung Hipotesis 3, di mana kepemilikan asing memiliki pengaruh dengan risiko yang terlibat dalam perdagangan saham; karena kepemilikan asing dikaitkan dengan risiko yang lebih tinggi. Jika pemiliknya, yaitu investor asing, adalah risk taker, maka risiko sahamnya meningkat. Investor internasional meningkatkan risiko karena risiko tersebut tidak hanya dihadapi oleh investor domestik tetapi juga oleh investor asing karena mereka memiliki andil dalam perekonomian negara.

\section{SIMPULAN}

\subsection{Kesimpulan}

Pengaruh kepemilikan asing pada variabelvariabel memberikan beberapa pengaruh dapat dilihat dari hasil pengujian hipotesis, pertama, kepemilikan asing dapat meningkatkan volatilitas saham dan semakin besar kepemilikan asing, semakin tinggi volatilitas return saham, karena dampak penguatan likuiditas dan volatilitas. Kedua, menemukan bahwa koefisien korelasi antara kepemilikan asing dan volume perdagangan harian secara signifikan negatif karena meningkatnya persaingan dalam proses penemuan harga. Ketiga, kepemilikan asing menyebabkan risiko saham yang tinggi karena Investor internasional meningkatkan risiko karena risiko tersebut tidak hanya dihadapi oleh investor domestik tetapi juga oleh investor asing karena mereka memiliki andil dalam perekonomian negara.

\subsection{Batasan dan Saran Penelitian Selanjutnya}

Pada penelitian ini, penelitian menyadari makalah ini mengandung banyak keterbatasan, yaitu data kami dibatasi hanya mencakup pada periode 2018-2020 karena sumber datanya. Perusahaan yang dijadikan sampel dalam penelitian hanya menggunakan saham-saham yang paling aktif yang terdaftar dalam indeks LQ45 di bursa efek indoensia. Dan nilai adjusted R2 yang cukup kecil 41,7 menunjukkan bahwa masih banyak faktor lain yang berpengaruh terhadap kepemilikan asing namun belum diuji dalam penelitian ini. Penelitian selanjutnya, penelitian ini dapat diperluas dengan memperpanjang tahun periode dan menggunakan metode tambahan dan masih banyak juga variabel makroekonomi lain yang mungkin signifikan dan dapat menjelaskan model tersebut.

\section{DAFTAR PUSTAKA}

Ahmad Maulin Naufa, I Wayan Nuka Lantara, Wee-Yeap Lau, The impact of foreign ownership on return volatility, volume, and stock risks: Evidence from ASEAN countries, Economic Analysis and Policy, Volume 64, 2019, Pages 221-235, ISSN

$0313-$ 5926,https://doi.org/10.1016/j.eap.201 9.09.002.

CEICdata.com. Indonesia Foreign Direct Investment. Ceicdata.com. Published June 2018. Accessed March 23, 2021. https://www.ceicdata.com/en/indicator /indonesia/foreign-direct-investment

Chen, Z., Du, J., Li, D., Ouyang, R., 2013. Does foreign institutional ownership increase return volatility? Evidence from China. J. Bank. Finance 37, 660669. 
Praxis : Jurnal Sains, Teknologi, Masyarakat dan Jejaring | Vol. 4 | No. 1 | September 2021

http://dx.doi.org/10.1016/j.jbankfin.20 12.10.006.

Chiang, Y.-C., Chan, M.-H., 2017. Foreign ownership and firm-level stock return volatility in Taiwan. Invest. Manag. Financ. Innov. 14, 261-269. http://dx.doi.org/10.21511/imfi.14(31).2017.10.

Data Harga Saham Harian Bursa Efek Indonesia | Dunia Investasi. Duniainvestasi.com. Published 2021. Accessed March 22, 2021. http://www.duniainvestasi.com/bei/

Dodd, O., Louca, C., Paudyal, K., 2015. The determinants of foreign trading volume of stocks listed in multiple markets. J. Econ. Bus. 79, 38-61. http://dx.doi.org/10.1016/j.jeconbus. 20 14.12.004.

Fiala, T., Havranek, T., 2017. The sources of contagion risk in a banking sector with foreign ownership. Econ. Model. 60 , 108-121. http://dx.doi.org/10.1016/j.econmod.2 016.08 .025 .

Ghadhab, I., 2016. The effect of additional foreign market presence on the trading volume of cross-listed/traded stocks. J. Multinatl. Financ. Manag. and Exchange Rate for all countries, variables, and period $=$ Yes 34, 18-27. http://dx.doi.org/10.1016/j.mulfin.201 5.12.002.

Jogiyanto Hartono, 2013. "Teori Portofolio dan Analisis Investasi", BPFE Yogyakarta, Edisi Kedelapan, Yogyakarta.

Kasmir. (2014). Bank dan Lembaga Keuangan Lainnya. Edisi Revisi, Cetakan keempatbelas, PT. Raja Grafindo Persada, Jakarta. Kasmir. (2014). Bank dan Lembaga Keuangan Lainnya. Edisi Revisi, Cetakan keempatbelas, PT. Raja Grafindo Persada, Jakarta.

Lassoued, N., Sassi, H., Ben Rejeb Attia, M., 2016. The impact of state and foreign ownership on banking risk: Evidence from the MENA countries. Res. Int. Bus. Finance 36, 167-178. http://dx.doi.org/10.1016/j.ribaf.2015. 09.014.

Mutua,Petterson K. 2015. The Relationship Between Domestic Investment Activity And Market Returns At The Nairobi Securities Exchange. College of Humanities and Social Sciences (CHSS).

Naufa AM, Lantara IWN, Lau W-Y. The impact of foreign ownership on return volatility, volume, and stock risks: Evidence from ASEAN countries. Economic Analysis and Policy. 2019;64:221-235. doi:10.1016/j.eap.2019.09.002

PT Bursa Efek Indonesia. PT Bursa Efek Indonesia. Published 2020. Accessed March 22, 2021. https://www.idx.co.id/perusahaantercatat/laporan-keuangan-dantahunan/

PT Kustodian Sentral Efek Indonesia Home. Ksei.co.id. Published 2020. Accessed March 22, 2021. https://www.ksei.co.id/

Suad, Husnan. 1994. Dasar-Dasar Teori Portofolio dan Analisis Sekuritas. Edisi Pertama., UPP - AMP YKPN Yogyakarta.

Yi-Chein, Chiang and Ming-han Chan (2017). Foreign ownership and firmlevel stock return volatility in Taiwan. Investment Management and Financial Innovations, 14(3), 261-269. 